\title{
Peningkatan Kemampuan Pedagogik Guru dalam Pembelajaran Daring melalui Penerapan Kuis Interaktif Daring
}

\section{Improving Teachers' Pedagogical Ability in Online Learning through the Application of Online Interactive Quizzes}

\author{
Helda Jolanda Pentury ${ }^{1}$, Itsar Bolo Rangka ${ }^{2}$, Anastasia Dewi Anggraeni* ${ }^{3}$ \\ Universitas Indraprasta PGRI, Jakarta, Indonesia \\ *Penulis Korespondensi \\ 1jolandapentury69@gmail.com, ${ }^{2}$ itsar@konselor.org, ${ }^{3}$ anastasia.unindra@gmail.com
}

Riwayat Artikel: Dikirim 6 Februari 2021; Diterima 19 Mei 2021; Diterbitkan 21 Mei 2021

\begin{abstract}
Abstrak
Belajar dari Rumah (BDR) secara dalam jaringan (daring) dan luar jaringan (luring) memang menjadi tantangan bagi guru dalam penerapannya. Metode pembelajaran yang kurang tepat dan tidak variatif merupakan masalah yang sering dihadapi para guru terutama dalam pembelajaran daring. Para guru juga harus belajar lebih kreatif lagi memilih media pembelajaran agar siswanya tidak merasa bosan. Agar pembelajaran daring (online) dapat berjalan dengan baik, efektif dan menyenangkan, maka diperlukan motivasi siswa dalam kegiatan pembelajaran tersebut. Selain motivasi siswa, kreativitas guru penting karena kreativitas merupakan salah satu faktor yang mempengaruhi keberhasilan dalam proses pembelajaran. Jika para guru termotivasi, kreatif dan mampu mengembangkan kemampuan pedagogik mereka, maka proses pembelajaran akan mencapai tujuannya. Kegiatan yang dilaksanakan dalam bentuk webinar dan pelatihan secara daring bagi para guru sekolah dasar dan menengah di daerah Pamulang, Tangerang Selatan ini bertujuan meningkatkan peran guru secara profesional dalam kemampuan intelektual, pedagogik juga kreativitas yang dapat membantu berkembangnya proses pembelajaran yang diberikan. Hasil dari kegiatan dengan jumlah peserta 37 orang guru ini, yaitu peningkatan kemampuan kompetensi pedagogik melalui pilihan dan penggunaan media pembelajaran yang kreatif, variatif dan interaktif dengan memanfaatkan aplikasi berupa kuis-kuis interaktif daring yang beragam, kreatif dan menarik. Maka, penerapan kuis interaktif daring merupakan solusi bagi pengembangan kompetensi guru dalam proses pembelajaran maupun penilaian, baik dalam bentuk proyek atau kinerja.
\end{abstract}

Kata kunci: Pedagogik guru, pembelajaran daring, BDR (Belajar Dari Rumah), kuis interaktif daring

\begin{abstract}
Learning from Home (BDR) in network (online) and offline (offline) is indeed a challenge for teachers in its application. Inaccurate and non-varied learning methods are problems that teachers often face, especially in online learning. Teachers also have to learn to be more creative in choosing learning media so that their students don't feel bored. Online learning can run well, be effective and fun it requires motivation and also creativity in these learning activities. Creativity is important because creativity is one of the factors that influence success in learning. If teachers are motivated and creative, they will improve their pedagogic ability well to achieve learning goals. The activity, which is carried out in the form of a webinar and workshop online for elementary and middle school teachers, increases the role of teachers professionally in intellectual, pedagogical, and creativity which can help develop the learning process given. The results of this activity are increasing teachers' pedagogic competences in the selection and use of creative, varieties, and interactive. So, applying online interactive quizzes become solutions in increasing teachers' pedagogic competence in learning and assessment, project or performance.
\end{abstract}

Keywords: Teachers' pedagogic, online learning, BDR (Learning from Home), online interactive quizzes

\section{PENDAHULUAN}

Kementerian Pendidikan dan Kebudayaan (Kemendikbud) menerbitkan Surat Edaran Nomor 15 Tahun 2020 tentang Pedoman Penyelenggaraan Belajar dari Rumah dalam Masa Darurat Penyebaran COVID-19. Tujuan pelaksanaan Belajar Dari Rumah (BDR) adalah untuk memastikan pemenuhan hak peserta didik untuk mendapatkan layanan 
pendidikan selama darurat COVID-19 (Kemendikbud, 2020).

Belajar dari Rumah (BDR) secara dalam jaringan (daring) dan luar jaringan (luring) memang menjadi tantangan bagi guru dalam penerapannya. Banyak pihak juga yang menyoroti praktik BDR yang dianggap masih memberatkan siswa. Oleh karena itu guru harus mampu mengembangkan kreativitas dan inovasi dalam pembelajaran. Para guru juga harus belajar lebih kreatif lagi agar siswanya tidak merasa bosan. Pembelajaran daring (online) dapat berjalan dengan baik, efektif dan menyenangkan diperlukan motivasi dalam kegiatan pembelajaran tersebut.

Motivasi siswa penting karena motivasi merupakan salah satu faktor yang mempengaruhi keberhasilan dalam belajar. Jika para siswa termotivasi maka mereka akan belajar dengan sungguh-sungguh untuk mencapai tujuan pembelajaran (Emda, 2017).

Agar tujuan pembelajaran ini dapat terwujud, maka diperlukan peran guru secara profesional dalam kemampuan intelektual, pedagogik, kecerdasan emosional juga kreativitas yang dapat membantu berkembangnya proses pembelajaran yang diberikan. Metode pembelajaran yang kurang tepat dan tidak variatif merupakan masalah yang sering dihadapi para guru terutama dalam pembelajaran daring.

Selain itu beberapa fenomena dan dampak yang terjadi dengan adanya situasi dan kondisi pandemik Covid-19 ini, menunjukkan bahwa para siswa belum optimal terlibat dalam kegiatan pembelajaran secara daring. Kurangnya kreativitas dan kompetensi guru dalam bidang teknologi juga merupakan dampak dari kurang aktifnya para siswa dalam berpartisipasi dan terlibat dalam kegiatan pembelajaran. Di samping itu, ketidaksiapan guru dan siswa mengalami pembelajaran daring selama pandemik ini merupakan gejala dan faktor sosial yang dialami hampir semua orang di seluruh dunia.
Para guru pun masih menerapkan metode konvensional, seperti ceramah yang monoton, diskusi dan menghafal dalam kegiatan pembelajaran daring. Padahal pembelajaran daring (online) perlu strategi, model dan metode-metode yang kreatif dan inovatif dengan menggunakan kecanggihan teknologi. Hampir sebagian besar guru masih menggunakan buku teks sebagai sumber belajar utama. Tugas, kuis dan penilaian pun masih berpusat pada buku teks. Maka, dengan kegiatan webinar ini, pendidik yang kreatif diharapkan dapat menggunakan bermacam-macam metode saat pembelajaran, tentunya disesuaikan dengan materi atau tema (Anggraeni, 2018).

Selain hal-hal tersebut, media pembelajaran yang kreatif dan inovatif sesuai perkembangan zaman dan kebutuhan siswa pun menjadi salah satu komponen pendukung yang dapat menstimulasi hasil belajar siswa dan performa kerja guru. Hal ini didukung oleh pendapat Nana Sudjana dan Ahmad Rivai (Nurrita, 2018) yang mengatakan bahwa media pembelajaran dapat mempertinggi proses belajar siswa dalam pembelajaran yang pada gilirannya diharapkan dapat mempertinggi hasil belajar yang dicapainya.

Tantangan dan fenomena di atas merupakan hal-hal yang dialami para siswa maupun para guru di sekolah Mater Dei Pamulang. Adapun kurangnya motivasi para siswa dan kurangnya kemampuan pedagogik para guru dalam kegiatan pembelajaran daring merupakan salah satu kendala yang perlu menjadi perhatian agar proses pembelajaran lebih aktif, inisiatif, semangat dan merangsang kreativitas para siswa mencapai hasil belajar yang lebih baik.

Kegiatan pengabdian kepada masyarakat melalui webinar dan workshop daring ini diharapkan dapat meningkatkan kemampuan intelektual, pedagogik, dan kecerdasan emosi para guru sehingga mereka dapat memberikan pembelajaran yang dapat meningkatkan motivasi para siswa. 
Program Pengabdian Masyarakat yang ini berjudul PKM Meningkatkan Motivasi Siswa di dalam Pembelajaran Daring Melalui Penerapan Kuis Interaktif Online.

\section{METODE}

Kegiatan pengabdian kepada masyarakat ini dikemas dalam bentuk webinar (seminar daring) dan lokakarya daring mengenai peningkatan kompetensi pedagogik para guru-guru sekolah dasar dan menengah melalui penggunaan media pembelajaran daring yang interaktif. Webinar dan lokakarya ini dilaksanakan melalui aplikasi Zoom Meeting dengan kapasitas 100 orang guru sekolah dasar dan menengah yang tersebar di beberapa kota se-Jabodetabek dengan pelaksanaan waktu selama 2 hari di hari Sabtu tanggal 5 dan 12 Desember 2020 Pukul 09.00 - 12.00 WIB. Prosedur pelaksanaan pertemuan Zoom ini dilakukan dengan cara membagikan tautan Zoom kepada peserta (guru) terlebih dahulu.

\section{HASIL DAN PEMBAHASAN}

Proses kegiatan webinar dan lokakarya online pada guru-guru dilaksanakan dengan memberikan materi penerapan media edukatif online dengan model pelatihan melalui webinar dan lokakarya online. Dari kegiatan webinar ini menunjukkan bahwa kemampuan guru dalam mengelola pembelajaran dengan menggunakan media digital edukatif lebih efektif dengan ikut terlibatnya mereka secara aktif dalam kegiatan yang dilaksanakan.

Untuk mengetahui keefektifan penerapan media pembelajaran edukatif daring seperti Quizziz, Kahoot dan lainnya kegiatan webinar dilanjutkan dengan kegiatan lokakarya (workshop) untuk memaksimalkan pelatihan penerapan media pembelajaran interaktif secara daring. Berikut hasil karya salah satu peserta membuat kuis interaktif dengan media Quizziz dan Kahoot.

Gambar 1:

Kuis Interaktif menggunakan Quizziz dan Kahoot
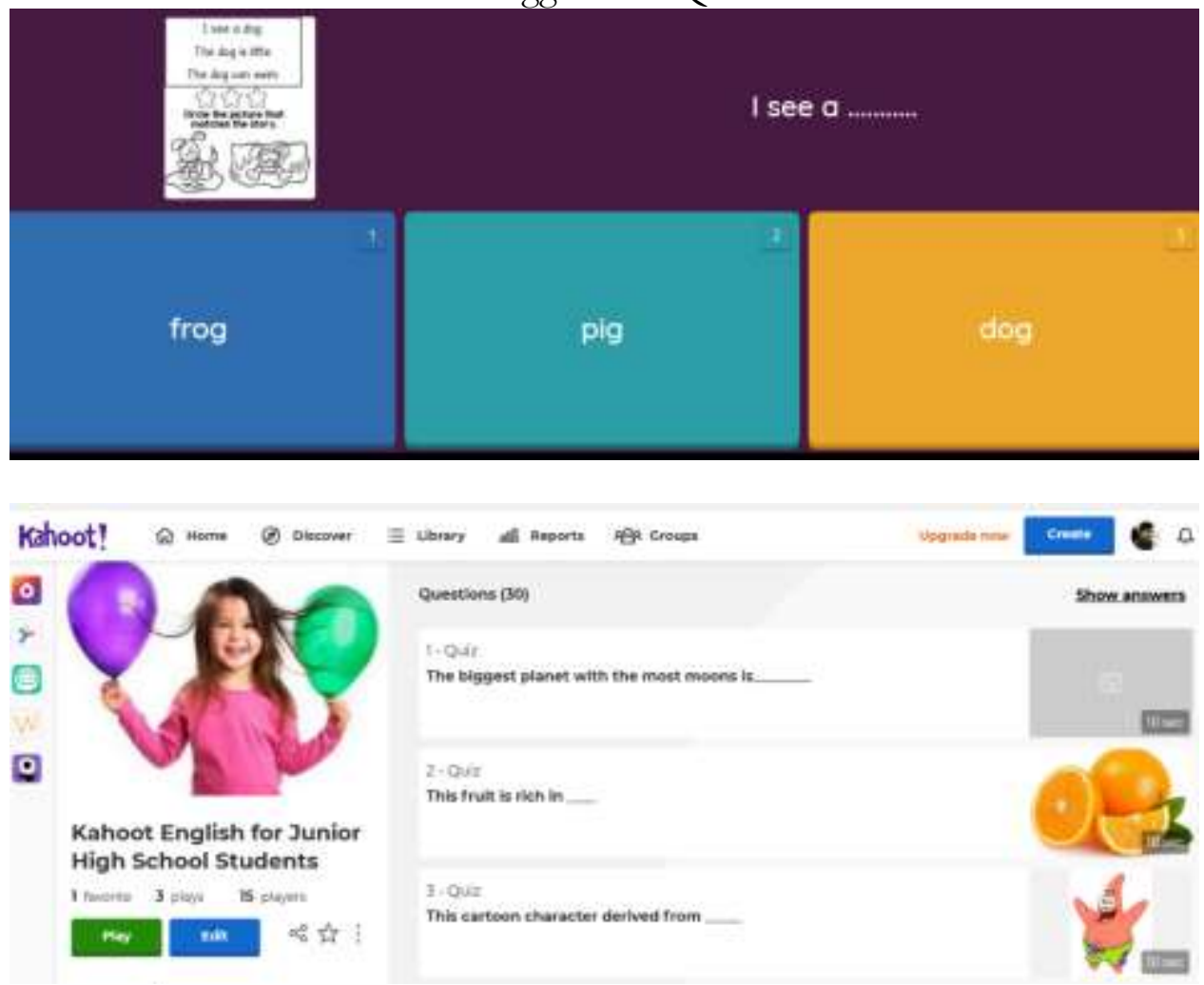
$\begin{array}{ccr}\text { Para } & \text { guru memperoleh } \\ \text { kesempatan } & \text { membangun } & \text { sendiri }\end{array}$ pengetahuannya sehingga memperoleh pemahaman dan pengalaman yang mendalam seperti meng-upload, mengdownload maupun mendemonstrasikan hasil praktik pelatihan yang diberikan. Peningkatan kemampuan pedagogik para guru ditunjukkan dengan suasana pelatihan yang kondusif, yakni kondisi tersedianya sumber belajar, termotivasinya para peserta untuk belajar dan terciptanya hubungan yang harmonis dengan para peserta serta peluang-peluang yang diberikan untuk mengembangkan kegiatan yang kreatif (Supriatna \& Maulidah, 2020). Hal ini menunjukkan perubahan pengembangan kompetensi para guru dengan menggunakan beragam strategi, metode dan pendekatan berbeda dari sebelumnya yaitu penggunaan buku teks sesuai dengan pelajaran yang diampu beralih ke pemanfaatan berbagai aplikasi kuis online dalam kegiatan pembelajaran yang lebih dinamis.

Selain itu, dalam proses pelatihan beberapa guru menunjukkan potensi mereka dengan mengeksplorasi dan mencoba berbagai kuis daring yang disediakan tim PkM, serta mengembangkan kemampuan pedagogik yang berbeda dan kontekstual sesuai kondisi lingkungan sebagai hasil belajar. Hal itu sesuai dengan pendapat yang disampaikan oleh (Nining Mariyaningsih, 2012), yaitu guru yang kompeten akan lebih mampu menciptakan lingkungan belajar yang efektif dan menyenangkan. Pelatihan yang efektif ini mampu meningkatkan kreativitas para guru dalam mengembangkan media pembelajaran yang lebih variatif, aktif, kreatif dan inovatif sesuai karakteristik pelajaran dan kebutuhan para peserta didik.

Menurut Uno (Nefida, 2016) menyatakan bahwa seorang guru perlu mengetahui dan dapat menerapkan beberapa prinsip mengajar agar ia dapat melaksanakan tugasnya secara profesional, antara lain guru harus dapat membangkitkan minat peserta didik untuk aktif dalam berpikir serta mencari dan menemukan sendiri pengetahuan. Selain itu, materi pembelajaran yang diberikan disesuaikan dengan kebutuhan para peserta melalui praktik pengembangan sebuah tema keseharian seperti "Penggunaan teknologi meningkatkan kreativitas guru dan siswa". Hal ini didukung oleh pendapat Mulyasa (Irmawati, 2013) yaitu materi pembelajaran hendaknya bersifat fleksibel, sesuai dengan kebutuhan dan lingkungan peserta didik. Berikut dokumentasi kegiatan PKM melalui webinar.

Gambar 2:

Dokumentasi Kegiatan PKM melalui Webinar

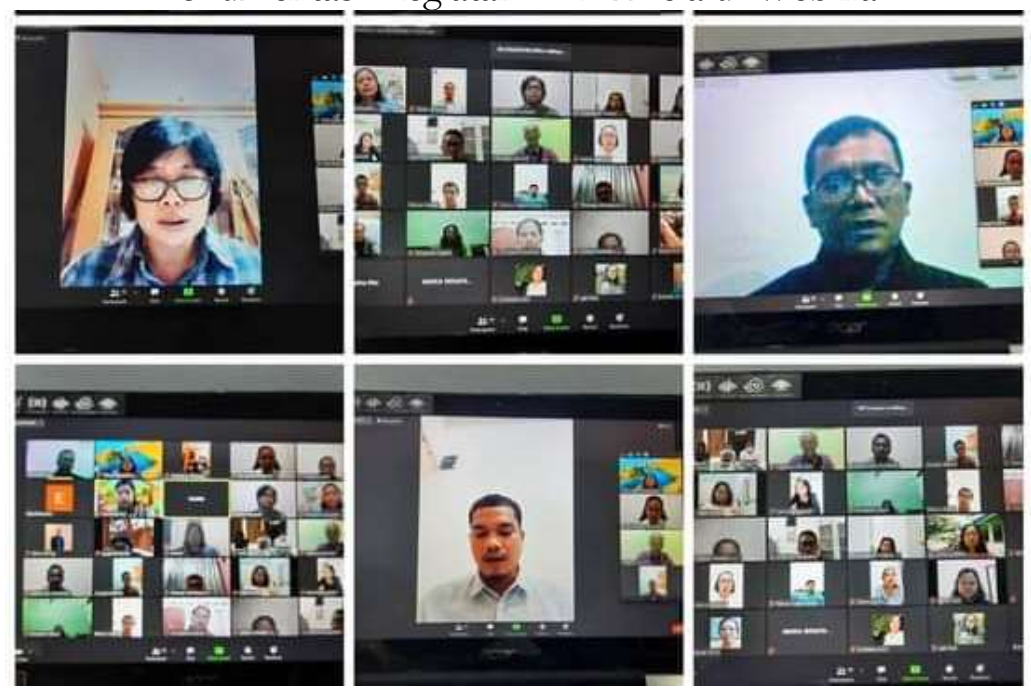


Beberapa hasil yang diperoleh selama pelaksanaan kegiatan pelatihan ini juga, antara lain:

1. Menstimulasi kemampuan pedagogik para guru akan potensi perkembangan teknologi informasi dan komunikasi yang dinamis sehingga mampu termotivasi dalam merancang dan mengembangkan model, strategi dan media pembelajaran yang sesuai dengan perkembangan jaman, kebutuhan peserta didik dan pembelajaran yang berkelanjutan.

2. Memotivasi para guru untuk bisa beradaptasi dengan perkembangan teknologi, sehingga dapat menerapkan kemampuan pedagogik mereka dalam pelaksanaan proses pembelajaran, maupun menjadi fasilitator.

3. Mengembangkan kemampuan para guru dalam belajar dan merancang media pembelajaran berbasis teknologi informasi dan komunikasi atau digital, sehingga proses pembelajaran lebih optimal, menarik, dan hasil belajar pun lebih efektif.

4. Mengembangkan kemampuan para guru lebih berinisiatif, berinovatif, kreatif dan bertanggungjawab dalam penggunaan media digital, sehingga para peserta didik pun mampu memahami dan menggunakan konsep, pengetahuan dan penerapan media digital dalam meningkatkan hasil belajar.

Pelatihan penerapan media pembelajaran interaktif daring ini efektif karena media yang digunakan adalah media pembelajaran yang mampu merangsang pikiran, perasaan, perhatian dan inisiatif, serta minat para guru sehingga mendukung terjadinya proses pelatihan yang interaktif, kreatif dan edukatif. Selama proses pelatihan dilaksanakan, penerapan media pembelajaran interaktif ini sangat membantu para guru dalam mengatasi keterbatasan pengalaman dengan mengeksplorasi dan mengembangkan imajinasi terhadap materi yang diberikan. Di samping itu, para guru pun mampu mengekspresikan diri dengan mencoba halhal baru. Media pembelajaran interaktif ini juga membantu para guru berkolaborasi dan bekerja sama dalam tim dengan baik. Namun, beberapa kendala yang terjadi dalam proses pelaksanaan kegiatan pelatihan ini, antara lain tidak semua guru menguasai keterampilan teknologi, dan tidak semua tempat domisili para guru memiliki jaringan internet yang mendukung.

Sependapat dengan hasil penelitian yang dilakukan oleh Helda Jolanda Pentury (Pentury, 2017), guru senantiasa belajar dan lebih fleksibel menggunakan kemampuan pedagogiknya agar dapat mengembangkan pembelajaran yang efektif, efisien dan kreatif. Sejalan dengan hasil penelitian yang dilakukan oleh Lestari (Kuncahyono et al., 2020) bahwa siswa akan termotivasi belajar jika peserta didik mengetahui akan diberikan kuis. Hal ini berkaitan juga dengan kompetensi pembuat soal tes tersebut. Dengan demikian pelatihan penerapan media pembelajaran interaktif daring dapat memotivasi para guru mengembangkan kemampuan pedagogik melalui strategi, metode dan pendekatan yang bervariasi dan kreatif melalui berbagai kuis daring sebagai media pembelajaran maupun penilaian yang inovatif dan kreatif. Di samping itu, pelatihan ini memberikan peluang bagi para guru meningkatkan peran dan potensi mereka sebagai fasilitator dalam menyediakan pembelajaran daring yang lebih efektif.

\section{KESIMPULAN}

Berdasarkan proses dan hasil pelaksanaan kegiatan pelatihan penerapan media pembelajaran digital interaktif yang telah dipaparkan, maka dapat disimpulkan bahwa efektivitas penerapan media pembelajaran daring dapat meningkatkan kemampuan pedagogik para guru dalam merancang, menyediakan dan mengembangkan proses pembelajaran yang lebih baik, menarik, interaktif dan efektif.

Penggunaan media pembelajaran interaktif digital atau daring dapat 
membantu mengembangkan dan meningkatkan proses belajar baik guru maupun peserta didik. Media digital yang menarik dengan karakteristik multimedia mampu menstimulasi performa kerja maupun belajar guru dan peserta didik.

Pelatihan lokakarya daring memberikan asupan kompetensi yang mendukung kompetensi pedagogik para guru untuk lebih profesional meningkatkan hasil belajar siswa.

\section{DAFTAR PUSTAKA}

Anggraeni, A. D. (2018). Metode Role Playing dalam Pembelajaran Profesi Kependidikan. Jurnal Pendidikan Progresif, $\quad 8(1)$, 29-35. https://doi.org/10.23960/jpp.v8.i1.2 01804

Emda, A. (2017). Kedudukan Motivasi Belajar Siswa dalam Pembelajaran. Lantanida Journal, 5(2), 93-196.

Irmawati. (2013). Analisis Kompetensi Profesional Guru di Sekolah Menengah Pertama. Jurnal Eklektika, 1(1).

Kemendikbud. (2020). Surat Edaran No. 15 Tabun 2020 Tentang Pedoman Penyelenggaraan Belajar Dari Rumah Dalam Masa Darurat Penyebaran Corona Virus Disease (COVID-19). 09, 1-12.

Kuncahyono, Suwandayani, B. I., \& Muzaki, A. (2020). Aplikasi E-Test "That Quiz" sebagai Digitalisasi Keterampilan Pembelajaran Abad 21 di Sekolah Indonesia Bangkok. Lectura: Jurnal Pendidikan, 11(2), 153-166.

Nefida, E. (2016). Peran Kompetensi Profesional dan Kompetensi Pedagogik Guru terhadap Prestasi Belajar Siswa Kelas X dan XI dalam Pembelajaran Bahasa Inggris di SMA Negeri 1 Lubuk Sikaping Kabupaten Pasaman.

Nining Mariyaningsih. (2012). Jurnal Pendidikan Ekonomi Dinamika Pendidikan Vol. VII, No. 1, Juni 2012 Hal. 1 - 7. VII(1), 1-7.
Nurrita, T. (2018). Pengembangan Media Pembelajaran Untuk Meningkatkan Hasil Belajar Siswa. MISYKAT: Jurnal Ilmu-Imu Al-Quran, Hadist, Syari'ab Dan Tarbiyah, 3(1), 171. https://doi.org/10.33511/misykat.v3 $\mathrm{n} 1.171$

Pentury, H. J. (2017). Pengembangan Kreativitas Guru dalam Pembelajaran Kreatif Pembelajaran Bahasa Inggris. Jurnal Ilmu Kependidikan, 4(3), 265-272.

Supriatna, N., \& Maulidah, N. (2020). Pedagogi Kreatif. Bandung: Remaja Rosdakarya. 